Pesq. Vet. Bras. 35(12):965-974, dezembro 2015 DOI: $10.1590 / \mathrm{S} 0100-736 \mathrm{X} 2015001200005$

\title{
Retrospective canine skin peripheral nerve sheath tumors data with emphasis on histologic, immunohistochemical and prognostic factors ${ }^{1}$
}

\begin{abstract}
Gisele S. Boos², Daniele M. Bassuino², Fabiana Wurster², Neusa B. Castro², Tatiane
T.N. Watanabe ${ }^{3}$, Gustavo S. Silva ${ }^{4}$, Luciana Sonne ${ }^{2}$ and David Driemeier ${ }^{2 *}$

ABSTRACT.- Boos G.S., Bassuino D.M., Wurster F., Castro N.B., Watanabe T.T.N., Silva G.S., Sonne L. \& Driemeier D. 2015. Retrospective canine skin peripheral nerve sheath tumors with emphasis on histologic, immunohistochemical and prognostic factors. Pesquisa Veterinária Brasileira 35(12):965-974. Setor de Patologia Veterinária, Faculdade de Veterinária, Universidade Federal do Rio Grande do Sul, Av. Bento Gonçalves 9090, Porto Alegre, RS 91540-000, Brazil. E-mail: davetpat@ufrgs.br

In this retrospective study was determined the frequency of canine skin peripheral nerve sheath tumors (PNST) in cases diagnosed by the Setor de Patologia Veterinária of the Universidade Federal do Rio Grande do Sul (SPV-UFRGS), Brazil, between the years 2000 and 2012. The canine profiles, as well as histological, immunohistochemical and prognostic aspects of the tumors were based on 70 samples, comprising 40 females, 29 males and one unspecified sample. Between 2000 and 2012, 2,984 skin tumors of dogs were diagnosed in the SPV-UFRGS, totaling $2.34 \%$ of skin neoplasms in dogs. Animals that comprised the largest amount of samples (43\%) were those with no breed (SRD), followed by German Shepherds (10\%). Females were more affected than males (40/70 - 57\% and 29/70 - 41\% respectively). Skin PNST of this research showed predominant localization on the limbs ( $40 \%$ in the forelimbs and $29 \%$ in the hindlimbs); affecting adult dogs, mostly aged between 8 and 11 years (54\%). The samples were routinely processed for hematoxylin and eosin, and were also evaluated by toluidine blue and Masson's trichrome staining, and immunohistochemistry (IHC) anti-vimentin, -S-100, -GFAP, -actin, von Willebrand factor and neurofilament. Anisocytosis and anisokaryosis, mitotic index, intratumoral necrosis, invasion of adjacent tissues, tumor location, local recurrence and metastasis were related to the diagnosis of benign (49/70) or malignant tumor (21/70). The Antoni A histological pattern was observed more frequently in benign tumors. The immunohistochemistry helped to diagnose PNST, and anti-vimentin and anti-protein S-100 showed the highest rates of immunostaining. Throughout statistical analysis of animals with tumor recurrence, it was found that the chance of an animal with a malignant peripheral nerve sheath tumor to develop recurrence is 4.61 times higher than in an animal that had a benign tumor.
\end{abstract}

INDEX TERMS: Dogs, peripheral nerve system, neoplasia, prognosis, Brazil.

\footnotetext{
${ }^{1}$ Received on April 21, 2015.

Accepted for publication on September 14, 2015.

${ }^{2}$ Setor de Patologia Veterinária, Faculdade de Veterinária, Universidade Federal do Rio Grande do Sul (UFRGS), Av. Bento Gonçalves 9090, Porto Alegre, RS 91540-000, Brazil. *Corresponding author: davetpat@ufrgs.br

${ }^{3}$ Università degli Studi di Milano, Dipartimento di Scienze Veterinarie e Sanità Pubblica, Via Festa del Perdono 7, Milano, 20122, Italy.

${ }^{4}$ Departamento de Medicina Veterinária Preventiva, Faculdade de Veterinária, UFRGS, Avenida Bento Gonçalves 9090, Bairro Agronomia, Porto Alegre, RS 91540-000.
}

RESUMO.- [Dados retrospectivos de tumores de bainha de nervo periférico na pele de cães com ênfase a fatores histológicos, imuno-histoquímicos e prognósticos.] Neste estudo retrospectivo foi determinada a frequência dos tumores de bainha de nervo periférico (TBNP) na pele de cães diagnosticados pelo Setor de Patologia Veterinária da Universidade Federal do Rio Grande do Sul (SPV-UFRGS), Brasil, no período de 2000 a 2012. 0 histórico dos cães, assim como a histologia, a imuno-histoquímica e o prognóstico em relação aos tumores foram baseados 
em 70 amostras histológicas, correspondendo a 40 fêmeas (57\%), 29 machos (41\%) e uma amostra sem a informação do sexo. De 2000 a 2012, foram diagnosticados 2984 tumores de pele de cães pelo SPV-UFRGS, totalizando 2,34\% das neoplasias em cães. A maior parte das amostras (43\%) foi proveniente de animais sem raça definida (SRD), seguidos pelos da raça Pastor Alemão (10\%). A localização predominante dos TBNP desta pesquisa ocorreu em membros (40\% em membro tóracico e $29 \%$ em membro pélvico), afetando principalmente cães de oito a 11 anos idade (54\%). As amostras foram processadas rotineiramente para coloração de Hematoxilina e eosina, e foram realizadas as colorações de azul de toluidina e tricrômio de Masson, assim como realizada imuno-histoquímica (IHQ) anti-vimentina, -S-100, -GFAP, -actina, von Willbrand e neurofilamento. Os fatores anisocitose e anisocariose, índice mitótico, necrose intratumoral, invasão tumoral em tecidos adjacentes, localização tumoral, local de recorrência e metástase foram relacionados com o diagnóstico de benignidade (49/70) ou malignidade (21/70). 0 padrão histológico de Antoni A foi observado com mais frequência em tumores benignos. A IHQ auxiliou no diagnóstico dos TBNP, com maiores índices de imunomarcação anti-vimentina e S-100. A análise estatística das amostras de animais que apresentaram recidiva tumoral evidenciou que a chance de um animal com tumor de bainha de nervo periférico maligno desenvolver recidiva é 4,61 vezes maior do que em animais que apresentam tumor benigno.

TERMOS DE INDEXAÇÃO: Cães, sistema nervoso periférico, neoplasia, prognóstico, Brasil.

\section{INTRODUCTION}

Mesenchymal tumors of the skin and soft tissue cover a wide variety of entities, some of uncertain classification (Goldschmidt \& Hendrick 2002). Amid these tumors, peripheral nerve sheath tumors (PNST), commonly diagnosed in humans (Weiss \& Goldblum 2001) and less frequently in domestic animals (Veazey et al. 1993, Omi et al. 1994, Nielsen et al. 2007, Schulman et al. 2009, Pavia et al. 2012, Pavarini et al. 2013), comprise a heterogeneous group of neoplasms with exceptionally confusing nomenclature (Gross et al. 2009).

The PNST include schwannomas - which usually display the morphological features of Antoni A and Antoni B as well as Verocay bodies - neurofibromas, perineuromas, traumatic neuroma and malignant tumors of peripheral nerve sheath. They are derived from myelinating cells of the peripheral nervous system and are composed of Schwann cells (Joshi 2012).

The recognition of variants of PNST is important for establishing the prognosis and management of the treatment of human patients (Rosai 2004). In veterinary medicine, the prognosis for PNST in dogs depends partly on the location of the tumor and the possibility of removal, once previously surgically resected tumors present guarded to poor prognosis (Brehm et al. 1995, Chijiwa, Uchida \& Tateyama 2004). The tumor classification is based on assessment of morphological criteria such as the degree of cell differentia- tion, invasion, overall cellularity, mitotic rate and necrosis, which are examined alone or combined are also used as a tool (Cullen, Page \& Misdorp 2002). Furthermore, there are also employed complementary diagnostic techniques such as IHC with the purpose of helping in the identification of cellular origin, with markers such as vimentin, S-100 protein, neurofilament and actin (Gerdes et al. 1984).

The main aim of this study is to determine the incidence of PNST in dogs diagnosed by the Setor de Patologia Veterinária, UFRGS. In addition to this objective, this contribution aims to determine which breed, gender, age groups and body location are most affected. Allied to this, it intended to describe immunohistochemical and histologic characteristics and prognosis of these tumors in the population studied.

\section{MATERIALS AND METHODS}

Samples selection. A retrospective study was carried out using the records of the Setor de Patologia Veterinária of the Universidade Federal do Rio Grande do Sul (SPV-UFRGS) comprising the archives from January 2000 to December 2012. Based on the results of previous histological exams, cases of dogs diagnosed with benign or malignant PNST were selected. From these, were reviewed history (breed, sex, age, tumor location) and histologic description. Concomitantly, veterinarians and/or owners were contacted to assess survival time and whether there was tumor recurrence.

Histology. The selected samples consisted of tissue previously fixed in $10 \%$ formalin solution and routinely processed for hematoxylin and eosin (HE), and for the special stainings of toluidine blue and Masson Trichrome (MT) Kit (EP-11-2013 Easy Path). According to the amount of pericellular connective tissue within the neoplasms, represented by the blue color in the histological sections stained by MT, the staining was classified as mild, moderate and severe.

Histological classification. The tumors were determined to be benign/malignant according to Cullen, Misdorp \& Page (2002) with factors such as capsule and delimitation; anisocytosis and anisokaryosis (determined as mild/moderate or severe); mitotic index; cellularity of the neoplasm; invasion to adjacent tissues; and intratumoral necrosis. It were also observed and described the structures of Verocay bodies, Antoni A and Antoni B neoplasm patterns, when present.

Immunohistochemistry. Fragments of tumors fixed in paraffin were cut into $3 \mu \mathrm{m}$-thick sections and adhered to microscope slides (StarFrost ${ }^{\circledR}$ Microscope Slides, Beveled Edge). It was applied the biotin peroxidase linked to streptavidin method (LSABHRP kit K0690, Dako), 20 minutes each step, and negative controls were concomitantly used. In Table 1 are summarized the antibodies used in this study, as well as antigen retrieval, dilution, chromogens used in the labeling and commercial reference of each antibody.

Prognosis. The following factors, considered as prognostic determinants were observed: anisocytosis and anisokaryosis; mitotic index; intratumoral necrosis; invasion to adjacent tissues; tumor location; local recurrence; and metastasis. All these factors were related to the diagnosis of benign or malignant tumor, and analyzed their statistical significance.

Statistical study. Concerning the prognosis, the frequency of distribution and descriptive statistics were used to characterize the occurrence of recurrent tumors ( $R$ software package MASS and Epicalc). Statistical analysis was performed using a multivariate logistic regression model (R software package Epicalc). The 
Table 1. Antibodies, antigen retrieval, dilution, chromogens and commercial reference of immunohistochemical protocols applied on tissues of dogs diagnosed with peripheral nerve sheath tumors at the Setor de Patologia Veterinária, UFRGS, during the years 2000-2012

\begin{tabular}{|c|c|c|c|c|}
\hline Antibody & Antigen retrieval & Dilution & Chromogen & $\begin{array}{l}\text { Commercial } \\
\text { reference }\end{array}$ \\
\hline $\begin{array}{l}\text { Polyclonal rabbit anti- } \\
\text { Glial fibrillary acidic } \\
\text { protein (GFAP) }\end{array}$ & $\begin{array}{c}\text { Tris EDTA pH } 9.0 \\
\text { pressure cooker } 100^{\circ} \mathrm{C}, 10^{\prime}\end{array}$ & $1: 500$ & DAB & $\begin{array}{l}\text { Z0334, Dako, } \\
\text { Carpinteria, CA, USA }\end{array}$ \\
\hline $\begin{array}{l}\text { Monoclonal mouse anti- } \\
\text { human smooth muscle } \\
\text { actin }\end{array}$ & $\begin{array}{c}\text { Tris EDTA pH } 9.0 \\
\text { pressure cooker } 120^{\circ} \mathrm{C}, 20^{\prime}\end{array}$ & $1: 100$ & DAB & $\begin{array}{c}\text { M0851, Dako, } \\
\text { Carpinteria, CA, USA }\end{array}$ \\
\hline $\begin{array}{l}\text { Polyclonal rabbit } \\
\text { anti-S-100 }\end{array}$ & $\begin{array}{c}\text { Citrate buffer pH } 6.0 \\
\text { pressure cooker } 96^{\circ} \mathrm{C}, 20^{\prime}\end{array}$ & $1: 200$ & AEC & $\begin{array}{c}\text { Z0311, Dako, } \\
\text { Carpinteria, CA, USA }\end{array}$ \\
\hline $\begin{array}{l}\text { Monoclonal mouse anti- } \\
\text { Vimentin, clone V9 }\end{array}$ & $\begin{array}{l}\text { Citrate buffer pH } 6.0 \\
\text { pressure cooker } 96^{\circ} \mathrm{C}, 20^{\prime}\end{array}$ & $1: 200$ & DAB & 18-002, Zymed \\
\hline $\begin{array}{l}\text { Polyclonal rabbit anti- } \\
\text { human Von Willebrand } \\
\text { factor }\end{array}$ & $\begin{array}{c}\text { Citrate buffer pH } 6.0 \\
\text { pressure cooker } 125^{\circ} \mathrm{C}, 3^{\prime}\end{array}$ & $1: 800$ & DAB & $\begin{array}{c}\text { A0082, Dako, } \\
\text { Carpinteria, CA, USA }\end{array}$ \\
\hline $\begin{array}{l}\text { Polyclonal rabbit anti- } \\
\text { bovine Neurofilament H } \\
\text { 200kDa }\end{array}$ & $\begin{array}{c}\text { Trypsin } 0.1 \%, 37^{\circ} \mathrm{C}, 10^{\prime} \\
\text { and citrate buffer pH } 6.0, \\
2^{\prime} \text { microwave }\end{array}$ & $1: 500$ & DAB & $\begin{array}{c}\text { AHP245, AbD } \\
\text { Serotec, Oxford, UK }\end{array}$ \\
\hline
\end{tabular}

dependent variable was defined as the occurrence of recurrence (yes or no).

The model was built starting with a univariate analysis for each risk factor offered. Independent variables with P-value $<0.20$ were selected and used to build the multivariate model. The variables that passed the univariate model were tested for control of confounding and multicollinearity. Subsequently, the model was developed through a process of manual systematic construction of the forward type.

\section{RESULTS}

\section{Descriptive data}

From 2000 to 2012, 2,984 tumors involving the skin of dogs were diagnosed in the SPV-UFRGS. Of these, 70 corresponded to PNST, totaling $2.34 \%$ of the skin neoplasms

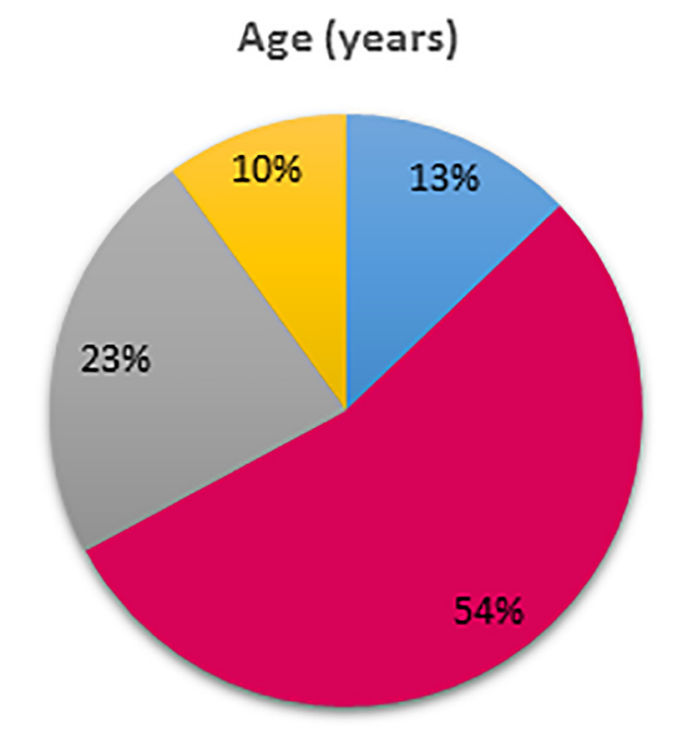

$$
\square 4-6 \square 8-11 \square 12-16 \square \text { Not informed }
$$

Fig.1. Age range in years of the 70 dogs with peripheral nerve sheath tumor diagnosed from January 2000 to December 2012.

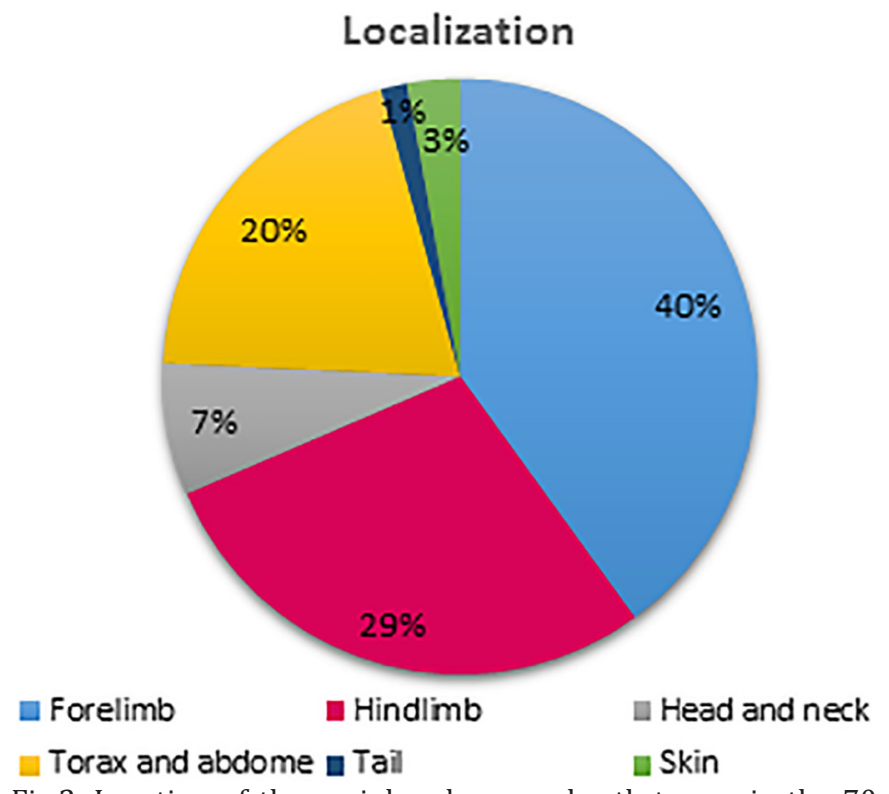

Fig.2. Location of the peripheral nerve sheath tumor in the 70 dogs diagnosed from January 2000 to December 2012.

in dogs. Animals that comprised the largest amount of samples of PNST (43\%) were those with no breed (SRD), followed by German Shepherds (10\%). Females were more affected than males $(40 / 70-57 \%$ and $29 / 70-41 \%$ respectively) and in one sample, sex was not reported. The results concerning the age of the dogs and tumor locations are shown in Figure 1 and 2. Concerning the time in which the tumor was observed until its excision, this finding was reported in $37 \%$ of the cases, ranging from three weeks to three years.

\section{Recurrence}

There was recurrence in 17 out of 70 samples, which corresponds to $24 \%$ of all cases. Between these 17 samples, seven (42\%) were benign tumors and 10 (58\%) were 


\section{Tumoral recurrence}

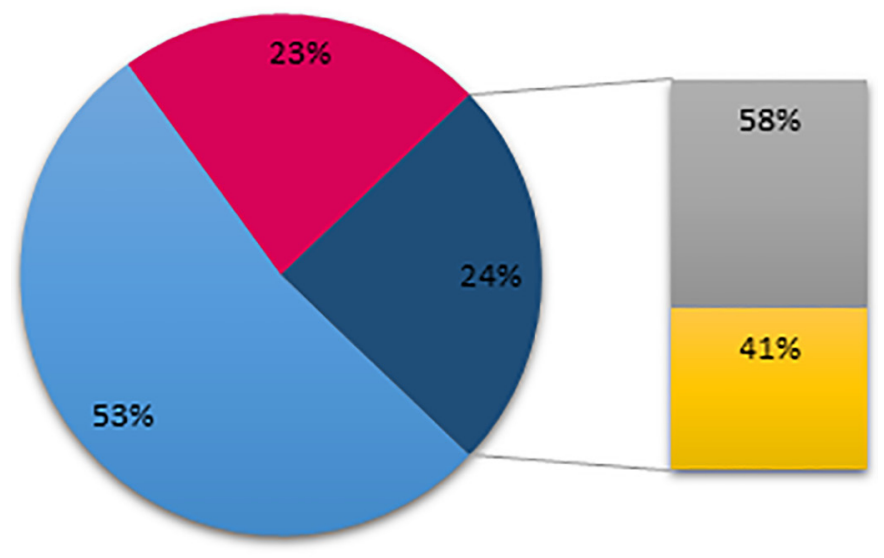

Non recurrent Not informed Malignant Benign

Fig.3. Recurrence of the peripheral nerve sheath tumors in the 70 dogs diagnosed from January 2000 to December 2012. The bar linked to the chart shows the recurrence according to the tumor status of malignant or benign.

malignant (Fig.3). Other 37/70 (53\%) dogs showed no recurrence until the day the research was closed, and veterinarians responsible for these cases reported that the returns occurred for routine visits such as vaccinations or other diseases unrelated to cancer.

From the total samples studied nine $(9 / 70)$, dogs died. Seven of them presented recurrence (7/9 - 77.78\%). Euthanasia was performed in two of these: the first 24 months after the first diagnosis of PNST by presenting pulmonary metastasis and liver mass; and the second, one month after removal of the tumor near the orbit due to chronic pain. Another one was sent to SPV-UFRGS and after the necropsy MPNST with pulmonary metastasis diagnose was established. The death of the other animals could not be related to the lesions studied.

\section{Benign peripheral nerve sheath tumors (BPNST)}

Two histologic patterns were distinguishable among the benign tumors (49/70 - 70\%). One approaches the classical model of human schwannomas (Fig.4) and the other can be compared to neurofibromas (Fig.5). The first pattern, detected in 43 out of 49 samples, comprises tumors located primarily in the dermis and subcutaneous tissue, delimitated and enclosed by a delicate connective tissue capsule, and moderate cellularity. They are composed predominantly of spindle cells forming elongated parallel bundles, bundles in different directions and sometimes whorls separated by a delicate fibrous stroma (Fig.4.A).

Antoni A areas were observed in 22 of the 43 tumors, and in seven of these (31.18\%), were observed Verocay bodies, arranged as bundles of spindle cells that intersect with acellular fibrillar material (Fig.4.B). Antoni A associated with Antoni B were observed in 17/43 (39.53\%) and tumors formed basically by Antoni B represented four out of 43 (30.9\%) samples. The cells forming Antoni A pattern were fusiform to elongate, with moderately distinct cell boundaries and abundant palely eosinophilic finely fibrillar cytoplasm (Fig.4.C,D). The cells forming Antoni B were round, with starry outline, and wide intercellular spaces, loosely arranged amid a myxoid matrix (Fig.4.E,F). The amount of pericellular collagen was much smaller than observed in the areas of Antoni A. Mitotic figures observed per high power field (40x), ranged from less than one $(18 / 43-41.86 \%)$ to one $(25 / 43-58.13 \%)$. Intratumoral necrosis was observed in 15/43 (34.88\%) and there was no invasion to adjacent tissues. Perivascular inflammatory infiltrate was observed in 11/43 (25.58\%), consisting mainly of lymphocytes.

The MT staining revealed pericellular and perivascular connective tissue, and was discretely in 24/43 (55.81\%) samples and moderately in 19/43 (44.18\%). In addition, it was observed a deposit of fibrous material around vessels in nine out of 43 lesions $(20.93 \%)$.

The second histologic pattern observed in BPNST corresponds to 6 out of 49 (12.24\%) tumors (Fig.5.A). The lesions showed no apparent proliferation immediately below the epithelium and had moderate cellularity (Fig.5.B). The cells were fusiform, forming bundles in different directions and surrounded by abundant fibrovascular tissue in MT staining, been slight positive for connective tissue in one out of six (16.66\%), moderate in two (33.33\%) and marked in three (50\%) (Fig.5.C). The cells were spindle-shaped, elongated and serpiginous with scant palely eosinophilic cytoplasm and indistinct edges. The nucleus followed the shape of the cell, and was hyperchromatic.

In two of the tumors it was possible to observe an area of Antoni A that occupies less than $30 \%$ of the lesions (Fig.5.D). Less than one mitotic figure was observed per 40x field in four of the tumors and in the other two, only one mitotic figure was observed on average. In all these lesions, it was observed mononuclear cell infiltrate evidenciated in toluidine blue staining, by an average of three labeled mast cells per $40 \mathrm{x}$ field. It was also observed, interspersed by tumor tissue, normal skin structural components such as glands, hair follicles and muscle.

\section{Malignant peripheral nerve sheath tumors (MPNST)}

Twenty-one $(30 \%)$ tumors were characterized as MPNST, they were localized in the subcutaneous tissue and rarely found in a capsule (one sample). They were not well delimitated, and invaded adjacent tissues such as superficial and deep dermis, adipose panicle and muscles. Invariably, they had high cellularity and were composed by cells organized occasionally in bundles, whorls and/or densely grouped forming lobes, surrounded by a thin fibrovascular stroma (Fig.6.A,B). Antoni A pattern was observed in 10/21 (47.61\%) lesions, Antoni A associated to Antoni B in seven (33.33\%), and none of these in four (19.04\%). Between areas of Antoni A, Verocay bodies were observed in four (19.04\%) samples. The cells' shapes ranged from spindle to round, frequently with indistinct borders. The cytoplasm was eosinophilic, and varied from homogenous to granular. The nucleus was spindle to round, sometimes eccentric, with chromatin coarsely dotted and nucleolus unique and evident, often magenta. 


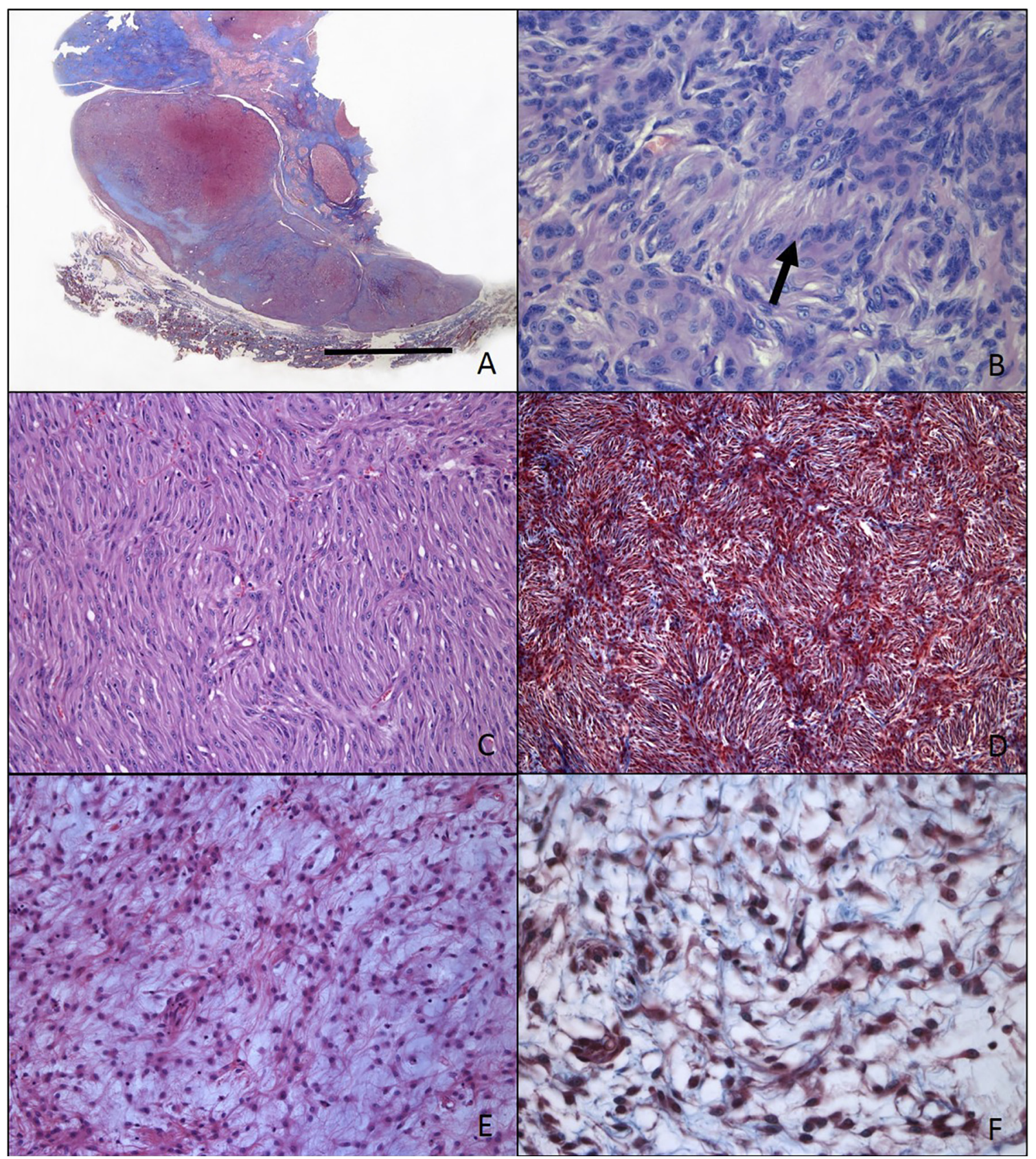

Fig.4. Benign peripheral nerve sheath skin tumors in dog. (A) Sub macroscopic image showing variations for connective tissue (blue), bar 1cm, Masson's trichrome (MT). (B) Bundles of spindle cells that intersect with central acellular fibrillar material - Verocay body (arrow). HE, obj.40x. (C) Spindle and elongated tumor cells arranged in parallel bundles - Antoni A pattern. HE, obj.20x. (D) Moderate amount of fibrovascular tissue surrounding tumor cells (blue) - Antoni A pattern. Masson's trichrome, obj.10x. (E) Rounded tumor cells with starry outline, and wide intercellular spaces, loosely arranged in a mucinous matrix - Antoni B pattern. HE, obj.20x. (F) Tumor cells with small amount of pericellular fibrovascular tissue - Antoni B pattern. Masson's trichrome, obj.40x.

Multinucleated cells were observed in two samples (Fig.6.C). Additionally, marked anisocytosis and anisokaryosis were seen in 12/21 (57.14\%), and moderate in nine $(42.85 \%)$. The number of mitotic figures varied from one to three per 40x field. Necrosis was observed in $13 / 21(61.9 \%)$ lesions, intratumoral hemorrhage in three $(14.28 \%)$, ulceration in two $(9.52 \%)$ and proliferation of fibrotic perivascular in six (28.57\%) tumors.

Masson Trichrome staining highlighted discretely the thin pericellular fibrovascular stroma in 15/21 (71.42\%); moderately in five $(23.8 \%)$ and accentuated in one (4.76\%).

Among the samples of MPNST, the result of the necropsy of one of the animals was re-evaluated, since the histological analysis showed pulmonary metastasis. The lung lesion was multifocal, and consisted of well-delimitated areas of moderate cellularity, with elongated to round cells, with pale eosinophilic cytoplasm, spindle to oval nucleus with coarse chromatin, unique and evident nucleolus (Fig.6.D). It was also observed moderate anisocytosis and anisoka- 


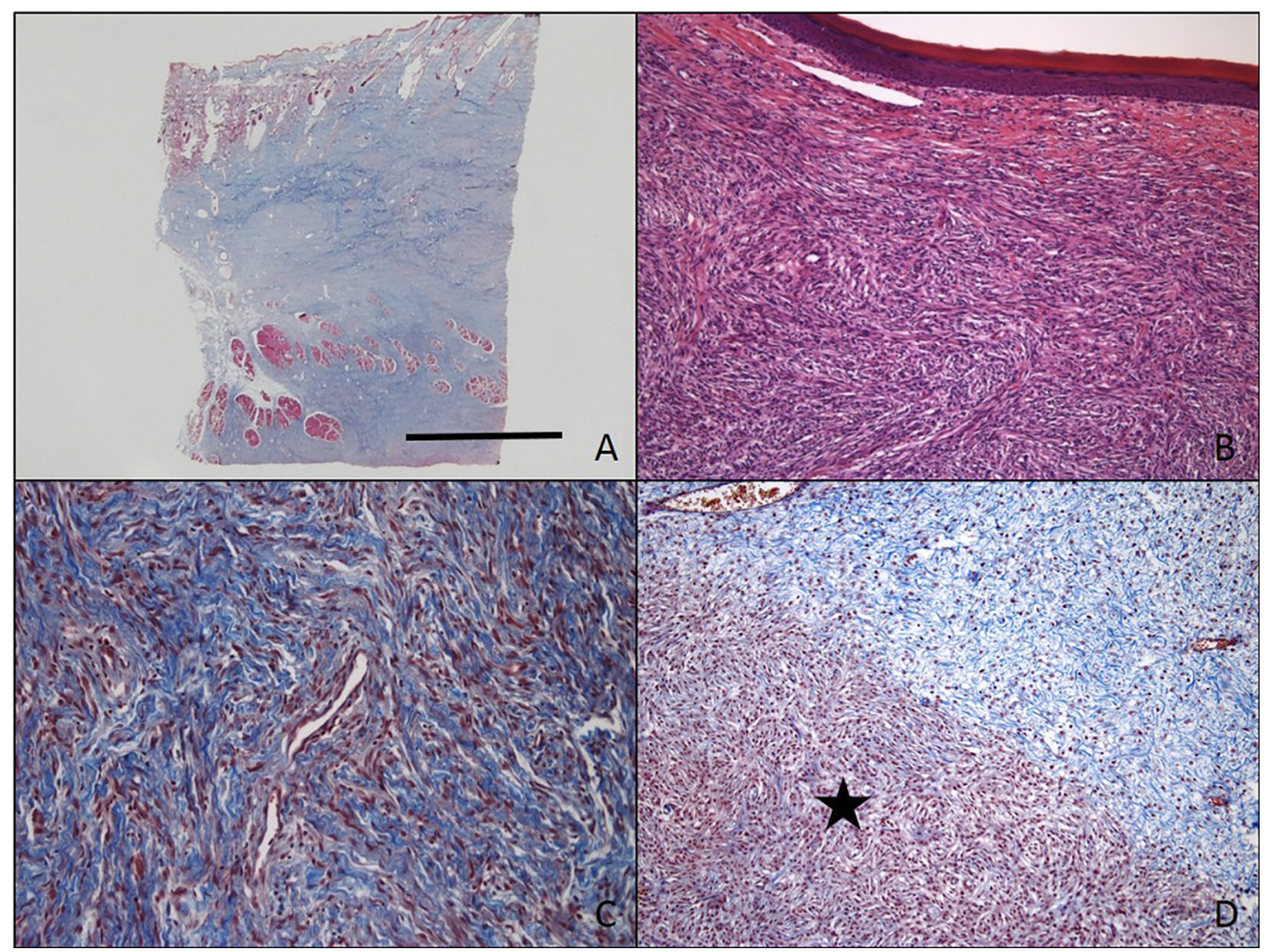

Fig.5. Benign peripheral nerve sheath skin tumor in dog. (A) Sub macroscopic image demonstrating large amount of intratumoral connective tissue (blue). Masson's trichrome, bar=1cm. (B) Proliferative lesion not delimitated, within the dermis, with moderate cellularity. HE, obj.10x. (C) Spindle cell tumor, forming bundles in different directions and surrounded by abundant fibrovascular tissue. Masson's trichrome, obj.20x. (D) Transition area between Antoni A pattern (star), and an area of tumor cells surrounded by abundant connective tissue (blue). Masson's trichrome, obj.10x.

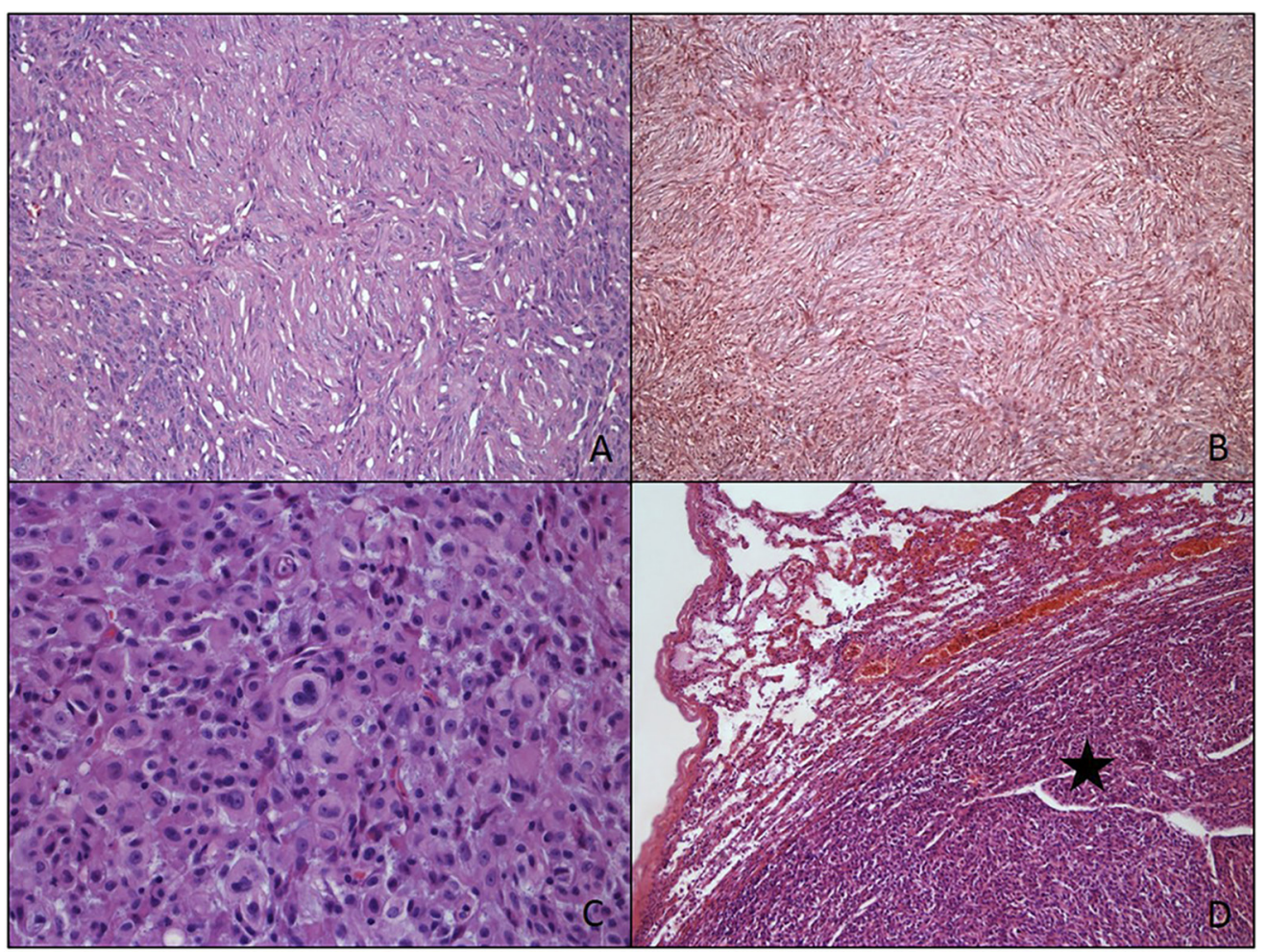

Fig.6. Malignant peripheral nerve sheath skin tumor in dog. (A) Skin; tumor cells arranged in palisades, with pale eosinophilic cytoplasm and indistinct edges. HE. obj.20x. (B) Skin; neoplastic cells in palisade containing discrete amount of pericellular fibrovascular tissue. Masson's trichrome, obj.20x. (C) Skin; tumor area of rounded cells, some multinucleated. HE, obj.40x. (D) Lung; area of tumor metastasis with rounded to elongated cells (star). HE, obj.10x. 


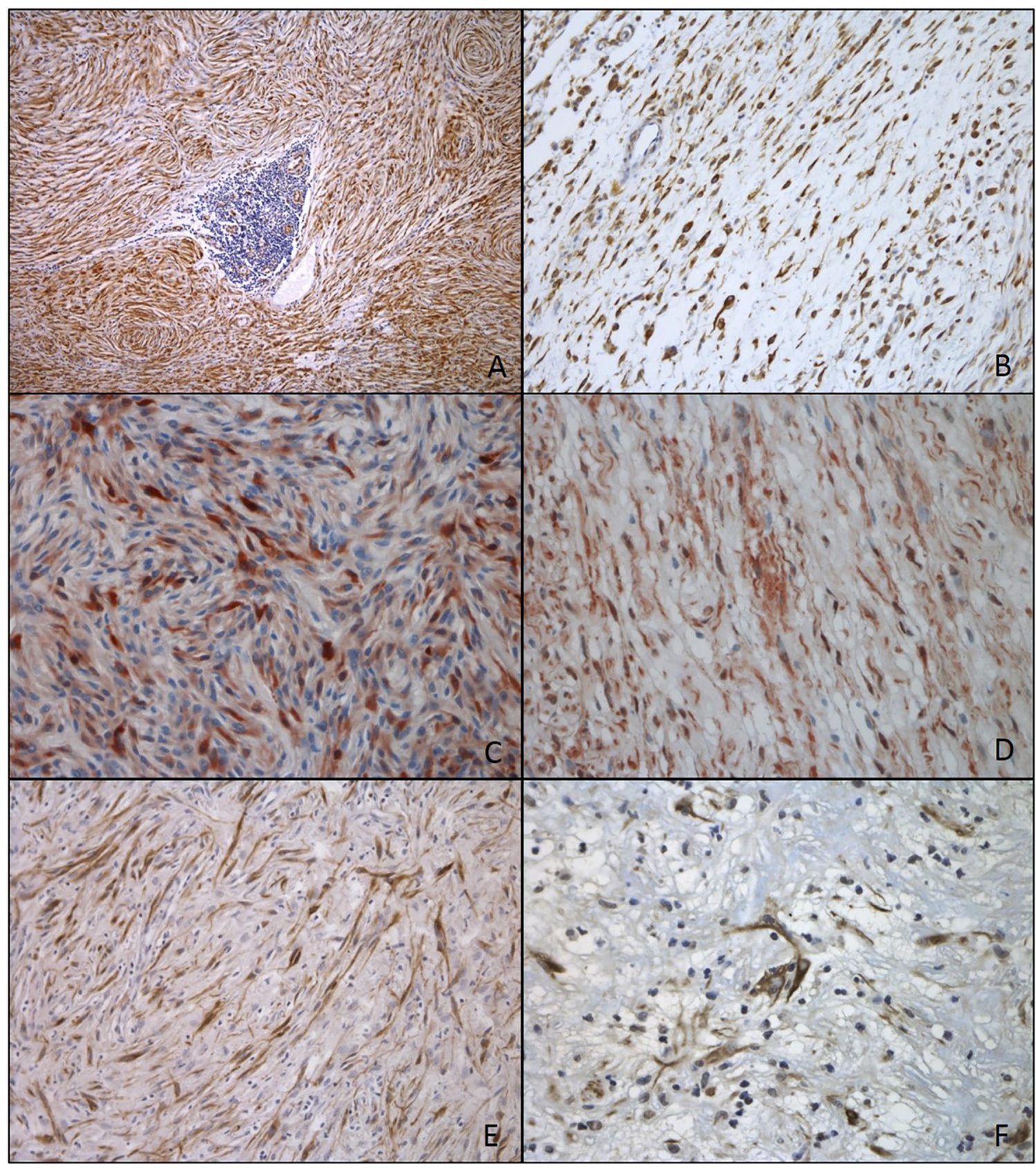

Fig.7. Peripheral nerve sheath skin tumor in dog. Immunohistochemistry, streptavidin-biotin method (LSAB). (A) Diffuse and accentuated cytoplasmic immunostainning of neoplastic spindle cells arranged in palisades and sometimes whorls, in the center, inflammatory infiltrate of lymphocytes. Obj.10x, anti-vimentin, DAB. (B) Cytoplasmic immunostainning of neoplastic cells arranged in parallel in a mucinous matrix (Antoni B pattern). Obj.20x, DAB. (C) Moderate cytoplasmic and nuclear immunostainning of spindle and elongated neoplastic cells. Obj.20x, anti-S-100, AEC. (D) Discrete to moderate cytoplasmic staining of spindle and serpiginous cells, background of non-reactive tissue. Obj.20x, anti-S-100, AEC. (E) Moderate cytoplasmic staining of spindle and elongated cells. Obj.20, anti-GFAP, DAB. (F) Accentuated and focal cytoplasmic staining of elongated cells with abundant cytoplasm, and positivity in anucleated, long and thin structures (arrow). Obj.40x, anti-Neurofilament, DAB.

ryosis, and the mitotic figures varied from one to two per 40x field.

\section{Immunohistochemistry}

Concerning anti-vimentin IHC, the neoplastic cells, including Antoni A (Fig.7.A) and Antoni B (Fig.7.B) patterns, had cytoplasmic immunostaining. The anti-S-100 protein immunolabeling was characterized by cytoplasmic and nuclear marking (Fig.7.C,D). Glial fibrillary acidic protein
(GFAP) occurred intensely, though rare in spindle and elongated cells, especially in benign tumors (Fig.7.E). None of the samples stained for actin, and one MPNST was positive for von Willebrand factor, marking a focal area of spindle cells. The other samples showed endothelial cells and occasional intratumoral blood vessels immunostaining.

When positive marking for neurofilament occurred, it happened in two distinct ways: in the lesions' periphery or interspersed in the other neoplastic cells. Stained cells 
were elongated and strongly stained, though in low numbers (Figure 7.F). There were also elongated, thin anucleated structures moderately stained.

The sample obtained from the necropsy exam showed moderate immunostaining for vimentin, discrete for S-100 and negative to the others. Further information regarding the immunostaining intensity to each antibody is found in Table 2.

\section{Statistics}

The prognosis of the dogs was based on the animals that had tumor recurrence. From data collected with the

Table 2. Immunohistochemistry of peripheral nerve sheath tumors, skin, dogs. Data concerning the staining intensity of benign and malignant tumors

\begin{tabular}{|c|c|c|c|c|c|c|c|c|c|c|c|c|c|c|}
\hline \multirow{2}{*}{$\begin{array}{l}\text { Tumor } \\
\text { type }\end{array}$} & \multirow{2}{*}{$\begin{array}{l}\text { Staining } \\
\text { intensity }\end{array}$} & \multirow[t]{2}{*}{$\mathrm{N}^{\mathrm{a}}$} & \multicolumn{2}{|c|}{ Vimen $^{c}$} & \multicolumn{2}{|c|}{ S-100 } & \multicolumn{2}{|c|}{ GFAP } & \multicolumn{2}{|c|}{ Actin } & \multicolumn{2}{|c|}{ V. Will ${ }^{\mathrm{d}}$} & \multicolumn{2}{|c|}{ Neurofe } \\
\hline & & & $\mathrm{n}^{\mathrm{b}}$ & $\%$ & $\mathrm{n}$ & $\%$ & $\mathrm{n}$ & $\%$ & $\mathrm{n}$ & $\%$ & $\mathrm{n}$ & $\%$ & $\mathrm{n}$ & $\%$ \\
\hline \multirow[t]{5}{*}{ Benign } & & 49 & & & & & & & & & & & & \\
\hline & Negative & & 0 & - & 0 & - & 29 & 59.2 & 49 & 100 & 49 & 100 & 41 & 83.7 \\
\hline & Discrete & & 4 & 8.2 & 10 & 20.4 & 12 & 24.5 & 0 & - & 0 & - & 8 & 16.3 \\
\hline & Moderate & & 10 & 20.4 & 27 & 55.1 & 6 & 12.2 & 0 & - & 0 & - & 0 & - \\
\hline & Accentuated & & 35 & 71.4 & 12 & 24.5 & 2 & 4.1 & 0 & - & 0 & - & 0 & - \\
\hline \multirow[t]{5}{*}{ Malignant } & & 21 & & & & & & & & & & & & \\
\hline & Negative & & 1 & 4.8 & 0 & - & 15 & 71.4 & 21 & 100 & 20 & 95.2 & 19 & 90.5 \\
\hline & Discrete & & 2 & 9.5 & 3 & 4.28 & 4 & 19.1 & 0 & - & 1 & 4.8 & 2 & 9.5 \\
\hline & Moderate & & 9 & 42.8 & 15 & 21.42 & 2 & 9.5 & 0 & - & 0 & - & 0 & - \\
\hline & Accentuated & & 9 & 42.8 & 3 & 4.28 & 0 & - & 0 & - & 0 & - & 0 & - \\
\hline
\end{tabular}

${ }^{a}$ Total number of tumors, benign $49(100 \%)$, malignant $21(100 \%)$; ${ }^{b}$ total number of samples stained with a certain amount of intensity (negative, discrete, moderate or accentuated); ${ }^{c}$ vimentin; ${ }^{\mathrm{d}}$ von Willebrand; e neurofilament.

Table 3. Distribution of the variables of peripheral nerve sheath tumors: tumor type (benign or malignant), sex, tumor location, anisocytosis and anisokaryosis, mitosis, cellularity, necrosis and tumor invasion to adjacent tissues; in relation to the tumoral recurrence category

\begin{tabular}{|c|c|c|c|c|c|c|}
\hline \multirow[t]{3}{*}{ Variable } & \multirow[t]{3}{*}{ Category } & \multirow[t]{3}{*}{$\mathrm{n}$} & \multicolumn{4}{|c|}{ Recurrence } \\
\hline & & & \multicolumn{2}{|r|}{ Yes } & \multicolumn{2}{|c|}{ No } \\
\hline & & & $\mathrm{n}$ & $\%$ & $\mathrm{~N}$ & $\%$ \\
\hline \multirow[t]{2}{*}{ Tumor type } & Benign & 37 & 7 & $18,92 \%$ & 30 & $81,08 \%$ \\
\hline & Malignant & 17 & 10 & $58,82 \%$ & 7 & $41,18 \%$ \\
\hline \multirow[t]{3}{*}{ Sex } & Female & 35 & 9 & $25,71 \%$ & 26 & $74,29 \%$ \\
\hline & Male & 18 & 7 & $38,89 \%$ & 11 & $61,11 \%$ \\
\hline & Not informed & 1 & 1 & $100,00 \%$ & 0 & \\
\hline \multirow[t]{4}{*}{ Location } & Head/neck/skin/tail & 20 & 6 & $30,00 \%$ & 14 & $70,00 \%$ \\
\hline & Thoracic limb & 18 & 3 & $16,67 \%$ & 15 & $83,33 \%$ \\
\hline & Pelvic limb & 11 & 6 & $54,55 \%$ & 5 & $45,45 \%$ \\
\hline & Thorax and abdomen & 5 & 2 & $40,00 \%$ & 3 & $60,00 \%$ \\
\hline \multirow[t]{2}{*}{ Anisocyt $^{\mathrm{a}} /$ anisok $^{\mathrm{b}}$} & Discrete / Moderate & 42 & 11 & $26,19 \%$ & 31 & $73,81 \%$ \\
\hline & Accentuated & 12 & 6 & $50,00 \%$ & 6 & $50,00 \%$ \\
\hline \multirow[t]{3}{*}{ Mitosis } & $<1$ & 18 & 2 & $11,11 \%$ & 16 & $88,89 \%$ \\
\hline & 1 & 27 & 9 & $33,33 \%$ & 18 & $66,67 \mathrm{nti} \%$ \\
\hline & $>2$ & 9 & 6 & $66,67 \%$ & 3 & $33,33 \%$ \\
\hline \multirow[t]{2}{*}{ Necrosis } & Yes & 20 & 6 & $30,00 \%$ & 14 & $70,00 \%$ \\
\hline & No & 34 & 11 & $32,35 \%$ & 23 & $67,65 \%$ \\
\hline \multirow[t]{3}{*}{ Invasion } & Not identifiable & 13 & 5 & $38,46 \%$ & 8 & $61,54 \%$ \\
\hline & No & 30 & 8 & $26,67 \%$ & 22 & $73,33 \%$ \\
\hline & Yes & 11 & 4 & $36,36 \%$ & 7 & $63,64 \%$ \\
\hline
\end{tabular}

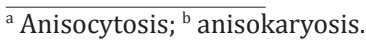

Table 4. Multivariate logistic regression model related to the risk factor for the occurrence of tumor recurrence in relation to the animal's age and the type of diagnosed tumor (malignant tumor)

\begin{tabular}{lccc}
\hline \multicolumn{1}{c}{ Variable } & \multicolumn{3}{c}{ Model } \\
\cline { 2 - 4 } & Odds ratio & $95 \%$ IC & P value \\
\hline Age $^{\mathrm{a}}$ & 1.26 & 1.031 .55 & 0.06373 \\
Tumor type (malignant) & 4.61 & 1.4714 .45 & 0.02808 \\
\hline${ }^{\mathrm{a}}$ Confounding. & & &
\end{tabular}

veterinarians responsible for each case, we could ascertain that $17(24.28 \%)$ out of 70 tumors studied recurred; 37 $(52.85 \%)$ did not, and this information could not be given about the other 16 cases, as we could not reach them. Table 3 summarizes the results obtained with the variables of tumor recurrence.

Table 4 presents the final logistic regression model. As a risk factor for tumor recurrence, the significant variable was the type of tumor presented ( $p=0.02808)$. The variable age was classified as confounding, being held in all steps of the forward model selection.

Thus, according to the analysis, the chance of an animal with malignant tumor to develop recurrence was $4.61 \mathrm{ti}$ mes higher than in an animal with benign tumor.

\section{DISCUSSION}

There is little information about the epidemiology of PNST in dogs. It is estimated that these injuries occur at incidences ranging from $0.5 \%$ to $2.41 \%$ among mesenchymal cutaneous neoplasms of dogs (Souza et al. 2006, Pakhrin et al. 2007). In this study, the incidence was of $2.34 \%$ of all skin tumors in dogs diagnosed by the SPV-UFRGS, and the prevalence of $70 \%$ of the BPNST has not yet been investigated by other researchers.

Regarding sex, females were more affected than males ( $57 \%$ and $41 \%$ respectively), which was also suggested by Gaitero et al. (2008). In dogs, it is still unproven that there is a hormonal factor explaining the relationship between sex and a higher incidence of PNST. However, in human medicine, it is speculated the involvement of growth hormone in the development of neurofibromas during puberty and development of neurofibromatosis during pregnancy (Fishbein et al. 2007).

Most of the dogs studied ranged from eight to eleven years old, followed by 12-16 years old, a characteristic doc- 
umented by other researchers (Viott et al. 2007, Gaitero et al. 2008). The explanation may be found at the high age ratio $\mathrm{x}$ neoplasia theory. It states that the accumulation of genetic damage over time, the decreased immune function, and a long time interval between the malignant transformation of a single cell and the emergence of a clinically detected neoplasm can be independent or interdependent explanations for the increased incidence of tumors in the last third of the animal's life (Cullen, Page \& Misdorp 2002, Viott et al. 2007, Gaitero et al. 2008).

Concerning the tumors' location, in this research and in others (Chijiwa, Uchida \& Tateyama 2004, Gaitero et al. 2008), forelimbs and hindlimbs were the most affected, where large nerves are located (Hung et al. 2010).

In human medicine, there is a sub classification of the PNST in schwannomas, neurofibromas and MPNST, as they show distinct clinic pathologic characteristics (Rosai 2004). Histologically, the benign tumors observed had two predominant patterns: one with the "classical" form of PNST, with evident Antoni A and Antoni B patterns, and occasionally, Verocay bodies. The other can be compared to the human neurofibromas (Rosai 2004) which exhibit an invasive behavior, as they 'englobe' normal adjacent structures (Rodriguez et al. 2012), a characteristic observed in two of our samples.

Furthermore, less homogeneous than the schwannomas, neurofibromas are formed by different cellular components, as the greater amount of pericellular connective tissue, detected by MT staining, and the variable amount of mast cells, stained by toluidine (Rodriguez et al. 2012). According to Cavanagh (1990), mast cells are seen in the endoneurial spaces and the number of these inflammatory cells increases when any injury to the peripheral nervous system occurs. In research conducted by Viott et al. (2007), the tumors diagnosed as schwannomas showed mast cells restricted to a few areas, while neurofibromas had higher concentrations.

About the malignant tumors, these were predominantly located in the subcutaneous tissue and invading adjacent tissues. They are characterized by high cellularity, and clusters of cells surrounded by a thin fibrovascular stroma, discreetly evident in MT staining. The standard Antoni A arrangement occurred in $47.61 \%$ of the lesions, but in less extensive areas than those seen in benign tumors. The reason why Schwann cells arrange in patterns Antoni A and B is not clear, but it has been observed that tumors initially arranged in Antoni A pattern can switch to the Antoni B after multiple transplants, and therefore, the pattern B could represent a primitive form, or an anaplastic state (Krinke 2011).

Regarding the IHC, vimentin and protein S-100 are two markers widely used both in human and in veterinary medicine. Vimentin is the typical intermediate filament of mesenchymal cells, and stains diffusely in BPNST (Mello \& Alves 1999, Gross et al. 2009). In this study, one of the MPNST cases was negative. Although normal tissue cells stain consistently, the neoplastic cells are uneven in standards of marking, and poorly differentiated tumors are less likely to express proteins typical of cells of origin of the tu- mor (Cullen, Page \& Misdorp 2002). In the benign tumors with other cell types such as fibroblasts, the tendency of staining was markedly diffuse in neoplastic cells, without staining the remainder of the tumor, composed of normal cells of the peripheral nervous system.

The positive staining for S-100 protein, although not as pronounced as the vimentin, is an important tool for differential diagnosis of fibrosarcomas, which do not exhibit this protein (Gross et al. 2009).

Among the other markers used in IHC, GFAP, an intermediate filament of astrocytes (Mello \& Alves 1999), showed positive and variable immunostaining intensity in benign and in malignant tumors. In humans, Kawahara et al. (1988) reported the occurrence of this marking especially in tumors located in the inner regions of the patients' body. This fact does not converge with the results obtained in this study, where the tumors marked by GFAP were mainly located in members. As noted in this study, BPNST are more often positive than MPNST, which could make this filament useful in distinguishing these variants (Enziger \& Weiss 2001, Gaitero et al. 2008).

A further recent theory about human tumors is the incidence of hybrid tumors and their positivity to GFAP. Most PNST, especially benign, exhibit distinctive morphological and immunophenotypic characteristics, what helps to determine the diagnosis. Occasionally, there are reports of PNST belonging to more than one category (Rodriguez et al. 2012). They have a basic cellular conformation (often schwannoma), added to other features of PNST such as perineuromas and neurofibromas (Spinner et al. 2007, Rodriguez et al. 2012). Besides humans, hybrid tumors have been diagnosed in dogs (Schöniger \& Summers 2009), cats (Schulman et al. 2009), and cattle (Nielsen, Jensen \& Leifsson 2011) and in two of our samples, that reminded to neurofibromas and positively stained for GFAP.

In the anti-neurofilament IHC, neurofibromas tend to have positive cells between tumoral cells, representing the behavior of nerve divulsion involved in the injury, unlike schwannomas, which tend to compress the adjacent nerve (Rosai 2004). For anti-von Willebrand IHC, reactivity was observed in a limited area of one malignant sample. This may be explained, according to Morphoulos et al. (1996) and Mello \& Alves (1999) as vascular neoplastic neuroectodermal differentiation.

Among the differential diagnosis that are often related to PNST, fibrosarcomas, previously discussed, hemangiopericytomas and amelanotic melanomas are frequently cited. The contrast between the histomorphology of MPNST and hemangiopericytomas is the less prominent spirals of the MPNST, which have also more delicate spindle cells and more intercellular matrix or fibrillar mucin than hemangiopericytomas (Hendrick et al. 1998). Besides these differences, the IHC for actin showed no positive staining, which would be expected of hemangiopericytomas (Gaitero et al. 2008). Regarding melanomas, which have cells that share the same embryological origin at the neural crest, as the Schwann cells (Banks 1992) tend to be positive to markers such as Melan-A and tyrosinase protein-2 (Choi \& Kusewitt 2003). 
The statistical analysis enabled to establish that the risk of an animal with malignant tumor will present recurrence is 4.61 times greater than an animal with a benign tumor. In the literature, both malignancy and recurrence of the tumor mean reserved to poor prognosis (Stark et al. 2001). Histologically, the lesions correspond to reports of cases of PNST in dogs (Hendrick et al. 1998). The distinction of factors that overlap or coexist in certain injuries, as well as the determination of the malignancy, take part at a proper diagnostic procedure (Rosai 2004). In this research, the histological evaluation associated with special staining techniques and IHC, allowed to establish the diagnoses. In addition, data were collected from the veterinarians and owners of the animals, and thus, the prognostic evaluation could be performed.

Acknowledgements.- We would like to thank Conselho Nacional de Desenvolvimento Científico e Tecnológico (CNPq) and Coordenação de Aperfeiçoamento de Pessoal de Nível Superior (CAPES) for financial support. We also thank Alessandra Boos for her comments on the early versions of this manuscript, as well as the veterinarians and owners of the animals studied.

\section{REFERENCES}

Banks W.J. 1992. Histologia Veterinária Aplicada. 2ª ed. Manole, São Paulo. $658 p$.

Brehm D.M., Vite C.H., Steinberg H.S., Haviland J. \& Van Winkle T. 1995. A retrospective evaluation of 51 cases of peripheral nerve sheath tumors in the dog. J. Am. Anim. Hosp. Assoc. 31(4):349-359.

Cavanagh J.B. 1990. Peripheral nervous system, p.533-543. In: Weller R.O. (Ed.), Nervous System, Muscle and Eyes. 3rd ed. Churchill Livingstone, London.

Chijiwa K., Uchida K. \& Tateyama S. 2004. Immunohistochemical evaluation of canine peripheral nerve sheath tumors and other soft tissue sarcomas. Vet. Pathol. 41(4):307-318.

Choi C. \& Kusewitt D.F. 2003. Comparison of tyrosinase-related protein-2, S-100, and Melan A immunoreactivity in canine amelanotic melanomas. Vet. Pathol. 40(6):713-718.

Cullen J.M., Page R. \& Misdorp W. 2002. An overview of cancer pathogenesis, diagnosis, and management, p.3-44. In: Meuten D.J. (Ed.), Tumors in Domestic Animals. 4th ed. Iowa State Press, Ames.

Enziger F.M. \& Weiss S.W. 2001. Soft tissue tumors, p.1405-1417. In: Weiss S.W. \& Goldblum J.R. (Eds), Enzinger and Weiss's Soft Tissue Tumors. 4 th ed. Mosby, St Louis.

Fishbein L., Zhang X., Fisher L.B., Li H., Campbell-Thompson M., Yachnis A., Rubenstein A., Muir D. \& Wallace M.R. 2007. In vitro studies of steroid hormones in neurofibromatosis 1 tumors and Schwann cells. Mol. Carcinogen. 46(7):512-523.

Gaitero L., Añor S., Fondevilla D. \& Pumarola M. 2008. Canine cutaneous spindle cell tumours with features of peripheral nerve sheath tumours: a histopathological and immunohistochemical study. J. Comp. Pathol. 139(1):16-23.

Gerdes J., Lemke H., Baisch H., Wacker H.H., Schwab U. \& Stein H. 1984. Cell cycle analysis of a cell proliferation-associated human nuclear antigen defined by the monoclonal antibody Ki-67. J. Immunol. 133(4):17101715.

Goldschmidt M.H. \& Hendrick M.J. 2002. Tumors of the skin and soft tissues, p.45-117. In: Meuten D.J. (Ed.), Tumors in Domestic Animals. 4th ed. Iowa State Press, Ames.

Gross T.L., Ihrke P.J., Walder J.E. \& Affolter K.V. 2009. Doenças de Pele do Cão e do Gato: diagnóstico clínico e histopatológico. 2nd ed. Roca, São Paulo. 904p.

Hendrick M.J., Mahaffrey E.A. \& Moore F.M. 1998. Histological classification of mesenchymal tumors of skin and soft tissues of domestic animals. Armed Forces of Pathology, Washington, DC. 62p.
Hung Y.W., Tse W.L., Cheng H.S. \& Ho P.C. 2010. Surgical excision for challenging upper limb nerve sheath tumours: a single centre retrospective review of treatment results. Hong Kong Med. J. 16(4):287-291.

Joshi R. 2012. Learning from eponyms: Jose Verocay bodies, Antoni A and B areas, Nils Antoni and schwannomas. Indian Dermatol. Online J. 3(3):215-219.

Kawahara E., Oda Y., Ooi Y., Katsuda S., Nakanishi I. \& Umeda S. 1988. Expression of glial fibrillary acidic protein (GFAP) in peripheral nerve sheath tumor: a comparative study of immunoreactivity of GFAP, vimentin, S-100 protein, and neurofilament in 38 schwannomas and 18 neurofibromas. Am. J. Surg. Pathol. 12(2):115-120.

Krinke G.J. 2011. Neuropathological analysis of the peripheral nervous system, p.365-384. In: Bolon B. \& Butt M.T. (Eds), Fundamental Neuropathology for Pathologists and Toxicologists: principles and techniques. Wiley, Hobokenl.

Mello E.S. \& Alves V.A.F. 1999. Glossário dos principais marcadores imuno-histoquímicos, p.260-262. In: Alves V.A.F., Bacchi C.E. \& Vassallo J. (Eds), Manual de Imuno-histoquímica. Sociedade Brasileira de Patologia, São Paulo. 270p.

Morphoulos G.D., Banerjee S.S., Ali H.H., Stewart M., Vasudev K.S., Eyden B.P. \& Harris M. 1996. Malignant peripheral nerve sheath tumour with vascular differentiation: a report of four cases. Histopathology 28(5):401-410.

Nielsen A.B., Jansen E.C., Leifsson P.S. \& Jensen H.E. 2007. Immunoreactivity of bovine schwannomas. J. Comp. Pathol. 137(4):224-230.

Nielsen A.B., Jensen H.E. \& Leifsson P.S. 2011. Immunohistochemistry for $2^{\prime}, 3^{\prime}$-cyclic nucleotide-3'-phosphohydrolase in 63 bovine peripheral nerve sheath tumors. Vet. Pathol. 48(7):796-802.

Omi K., Kitano Y., Agawa H. \& Kadota K. 1994. An immunohistochemical study of peripheral neuroblastoma, ganglioneuroblastoma, anaplastic genglioma, schwannoma and neurofibroma in cattle. J. Comp. Pathol. 111(1):1-14.

Pavarini S.P., Gomes D.C., Bandinelli M.B., Wouters F., Sonne L., Driemeier D. \& Farias da Cruz C.E. 2013. Malignant peripheral nerve sheath tumor as a cause of chronic cardiac insufficiency in cattle. Acta Vet. Scand. 55(7):1-6.

Pavia P.R., Having M.E., Donovan T.A. \& Craft D. 2012. Malignant peripheral nerve sheath tumor of the urinary bladder in a cat. J. Small Anim. Pract. 53(4):245-248.

Rodriguez F.J., Folpe A.L., Giannini C. \& Perry A. 2012. Pathology of peripheral nerve sheath tumors: diagnostic overview and update on selected diagnostic problems. Acta Neuropathol. 123(3):295-319.

Rosai J. 2004. Soft tissues, p.2105-2232. In: Ibid. (Ed.), Rosai and Ackerman's Surgical Pathology. Vol.2. 9th ed. Mosby Elsevier, London. 2977p.

Schöniger S. \& Summers B.A. 2009. Localized, plexiform, diffuse, and other variants of neurofibroma in 12 dogs, two horses, and a chicken. Vet. Pathol. 46(5):904-915.

Schulman F.Y., Johnson T.O., Facemire P.R. \& Fanburg-Smith J.C. 2009. Feline peripheral nerve sheath tumors: histologic, immunohistochemical, and clinicopathological correlation (59 tumors in 53 cats). Vet. Pathol. 46(6):1166-1180.

Souza T.M., Fighera R.A., Irigoyen L.F. \& Barros C.S.L. 2006. Estudo retrospectivo de 761 tumores cutâneos em cães. Ciência Rural 36(2):555-560.

Spinner R.J., Scheithauer B.W., Perry A., Amrami K.K., Emnett R. \& Gutmann D.H. 2007. Colocalized cellular schwannoma and plexiform neurofibroma in the absence of neurofibromatosis: case report. J. Neurosurg. 107(2):435-439.

Stark A.M., Buhl R., Hugo H.H. \& Mehdorn H.M. 2001. Malignant peripheral nerve sheath tumours - report of 8 cases and review of the literature. Acta Neurochir. 143(4):357-364.

Veazey R.S., Angel K.L., Snider T.G. 3rd, Lopez M.K. \& Taylor H.W. 1993. Malignant schwannoma in a goat. J. Vet. Diagn. Invest. 5(3):454-458.

Viott A.M., Ramos A.T., Inkelmann M.A., Kommers G.D. \& Graça D.L. 2007. Aspectos histoquímicos e imunoistoquímicos nos neoplasmas do sistema nervoso periférico. Arq. Bras. Med. Vet. Zootec. 59(5):1145-1153.

Weiss S.W. \& Goldblum J.R. 2001. Benign tumor of the peripheral nerves, p.1111-1208. In: Ibid. (Eds), Enzinger and Weiss's Soft Tissue Tumors. 4th ed. Mosby, St Louis. 